Kohl: a Journal for Body and Gender Research

Vol. 4, No. 1 (Summer 2018)

\title{
Slowing It Down: Embodied Complicity and the Challenges of Feminist Solidarity at the 2017 Beirut Workers' Day March
}

\author{
Allison Finn
}

\begin{abstract}
:
Complicity and coloniality are not abstract forces, but deeply personal experiences and questions. Through an ethnographic meditation of the 2017 Beirut Workers' Day March, this paper explores how feminist activists, researchers, and advocates can openly work through moments in which we are complicit in oppression. Drawing on Sara Ahmed's concept of encounter as method, the author reflects on the dynamics of solidarity, sponsorship, control, and privilege at the march, an annual event calling for the rights of migrant domestic workers and an end of the kafala (sponsorship) system in Lebanon, coorganized by migrant domestic worker activists, non-governmental organizations, and feminist communities. The paper contextualizes the encounter by defining the kafala system as a patriarchal state structure, proposes a distinction between "complicit feminisms" and moments of feminist complicity, and explores how coloniality infiltrates individual bodies and collective action. Then, the author relays her experience of embodied privilege and systems of control at the march, as a feminist supporter and volunteer member of the security team charged with keeping protestors safe. This paper builds on traditions of feminist self-critique and celebration, in analyzing the struggles and successes of solidarity between migrant domestic worker activists and feminist communities in Beirut. Complicity is inevitable when our bodies are markers of privilege, even when we are engaged in feminist, anti-racist, and anticapitalist practices. This does not mean that we should uniformly retreat, but that we need to interrogate our good intentions and the way that power is constructed within our bodies, and adapt - tactically, individually, and collectively.
\end{abstract}


On April 30, 2017, hundreds of people marched through the streets of Beirut from Sodeco Square to the Corniche, to call for an end to the kafala (sponsorship) system and advocate for basic rights for migrant domestic workers and migrant workers in Lebanon. The Workers' Day march has become an annual event in Beirut, held on or near Labor Day on May $1 .{ }^{1}$ Women migrant domestic workers ${ }^{2}$ lead the march themselves. This is no small feat. Their existence in Lebanon is governed by the oppressive kafala system, a set of administrative practices - not laws - that regulate the lives and labor conditions of temporary migrant workers. This system ties a migrant worker's immigration and legal status, ability to change her employment, freedom of movement, and ability to leave Lebanon to an individual employer, referred to as her sponsor or kafeel. ${ }^{3}$ Beyond the kafala system's formal practices, migrant domestic workers are also subject to harassment and constant uncertainty due to their gender, nationality, race, legal status, and devalued role in performing reproductive labor. ${ }^{4}$ At its essence, kafala represents both patriarchal state control and the race to the bottom for cheap, globalized labor. It serves those with economic and social capital, at the expense of people who inhabit Asian and African, poor, and often female bodies.

As a member of a feminist group supporting the 2017 march, and an individual, I volunteered for the "security team," charged with addressing any conflicts with police or bystanders. Our goal was to protect marchers from the risks inherent in public visibility and activism, when many lack legal residency and work permits, and arrest can mean deportation regardless of legal status. When I signed up, I imagined we would offer our bodies - with our Lebanese or Western passports and all the associated privilege - as a barrier against outside forces that control, police, and harass migrant domestic worker activists on a daily basis. I imagined that our presence would amplify workers' calls to end the kafala system, and the economic, physical, sexual, racial, and psychological violence woven into its core.

However, patriarchal oppression and globalized capitalism are insidious; they pervade even our acts of resistance. By the very act of protection of workers' bodies, and the mandate to keep things organized, I joined the many systems that control and police the actions of migrant domestic workers. I contributed to the common narratives of vulnerability and victimhood, and the kafala system's myths of dependency and protectionism. I showed up in feminist solidarity, but left wondering if I had done more harm than good.

In this paper, I explore how people who engage in feminist, anti-racist, and anti-capitalist work find themselves supporting the same kinds of power and authority that they claim and aim to oppose. I draw on ethnographic reflection of the 2017 Workers' Day March in Beirut, as well as a literature review and

\footnotetext{
1 Chamoun and Ayoub, 2017.

2 I use "migrant domestic worker" with full acknowledgement of the reductionism of identity, for lack of more just language. I differentiate between migrant domestic worker activists and Lebanese feminist activists, because of their varied privileges and access to power.

3 International Labour Organization, 2017.

4 Reproductive labor typically refers to domestic and caregiving work, which includes cooking, cleaning, and caring for children and the elderly. It can be paid or unpaid.
} 
conversations around migrant domestic worker activism in Lebanon, the women's movement in Beirut, NGOization, interrogations of feminist activism versus practice, and notions of complicity and coloniality. My focus is on feminist solidarity, but that intersects with struggles for fair labor standards, alternatives to capitalism, and the racialized hierarchies reproduced by globalized capitalism.

Methodologically, I draw on Sara Ahmed's concept of encounters as method 5 and Tiffany Page's exploration of vulnerability in writing as feminist research method. ${ }^{6}$ Ahmed advocates for personal and scholarly investigation of meetings with another person or an idea, and exploring the power structures ingrained in these moments. Page investigates the vulnerability, and the ethics, of telling emotional stories that are not your own. She encourages exploration of the unsettling, and that which cannot be easily explained, in a counter to neoliberal academic policies that demand assertive declarations of fact. ${ }^{7}$

In choosing the term "encounter" to describe my experience at the march, I do not intend to signify an unexpected meeting with an embodied other, as Ahmed does. Rather, I refer to an encounter with myself, and the communities I inhabit. My reflections on the march thus include both observation of power dynamics, and personal, embodied experience of race, class, and nationality privilege. Through a meditation on one such moment of the 2017 march, I ask: How can we, as feminist activists, researchers, and advocates, openly work through moments in which we are complicit in oppression?

\section{Life Under the Kafala System}

The International Labour Organization estimates there are at least 250,000 migrant domestic workers in Lebanon, the vast majority of whom are women from Asia and Africa. ${ }^{8}$ They provide much of the reproductive labor sustaining the country. Many live and work in Lebanese homes, where they cook, clean, wash, raise children, and care for the elderly. Some women live on their own, "freelancing" and working in multiple houses or businesses. Others work in hotels or spas. Workers leave their own families behind in Ethiopia, Sri Lanka, the Philippines, Nepal, Kenya, Madagascar, and beyond, in exchange for salaries as low as $\$ 150$ a month. 9

Domestic workers are not included in the Lebanese labor law. ${ }^{10}$ This means that rampant exploitation of workers by employers, recruitment agencies, and the state does not violate Lebanese law. This also prevents migrant domestic workers from legally unionizing and organizing for their rights. ${ }^{11}$

\footnotetext{
${ }^{5}$ Ahmed, 2000.

6 Page, 2017.

7 Page, 2017, 20.

8 International Labour Organization, 2016, 1.

9 International Labour Organization, 2016, 9.

10 Hamill, 2012.

11 Tayah, 2017.
} 
In 2009, the ILO and Lebanese Ministry of Labor introduced a standard unified contract, intended to combat abuse, but it has done little to change the reality for most workers. ${ }^{12}$ It is a worker's right to be paid each month, to keep her passport, and to have a day off - but she cannot unilaterally break her contract for these reasons. ${ }^{13}$ The administrative regulations and unwritten rules of kafala instead promote physical, psychological, and bodily confinement, monitoring, and control, whether a worker finds herself within the "legal" system or outside of it. Employment agencies charge thousands of dollars in recruitment fees and placement of workers. Many employers confiscate passports and residency permits. ${ }^{14}$ Many of them lock workers in the home, refuse to give a day off, and withhold wages. An employer is only obligated to pay for a return ticket if the worker finishes her two- or three-year term. If her kafeel is abusive, she still needs their permission to seek a new employer. Migrant domestic workers are sometimes deported for having children. ${ }^{15}$ Two workers die each week, many from suicide or attempts to escape abuse. ${ }^{16}$

In a system that produces such a drastic power imbalance, abuse and violence are rampant and underreported. ${ }^{17}$ Crimes are largely undocumented by the state. For migrant domestic worker activist groups, non-governmental organizations (NGOs), and advocates, it is hard to quantify the physical, sexual, and psychological violations that go even further. How do you measure rates of violence, when women cannot leave the homes where assaults occur, and where those who do escape become "illegal?"

Migrant domestic workers are commonly understood through the narratives of the kafala system, and from academic and NGO portrayals of women's precariousness and vulnerability. ${ }^{18}$ Practically, women migrant domestic workers' lives are governed by the kafala system's twin myths of dependency and danger: the worker supposedly needs the protection of her employer to function in daily life, but the employer also needs protection from her. In an interview with journalist Heba Kanso, Georges Ayda, General Director of the Ministry of Labor, justified the kafala system with this rhetoric of protection, stating, "When they work in houses there has to be somebody that is responsible for them. You are putting a stranger within a family."19

A live-in worker is, at the start, a stranger to the family she works for, and the apartment or house she lives in. But Ayda's words, and testimonies from migrant domestic workers, ${ }^{20}$ emphasize that she is also considered a stranger in her otherness, her skin, her language. As is evident in the testimonies from countless women, migrant domestic workers are not treated like humans. ${ }^{21}$ In 2016, Cameroonian activist and migrant domestic worker Rose told Kohl: a Journal for Body and Gender Research that, upon her

\footnotetext{
12 Hamati, 2016.

13 Ministry of Labour Lebanon and International Labour Organization, 2012.

14 International Labour Organization, 2016.

15 Hamati, 2016, 17-18; Ministry of Labour Lebanon and International Labour Organization, 2016, 22. Hamati notes that an estimated 10,000 MDWs have children in Lebanon.

${ }^{16} \mathrm{Su}, 2017$.

17 Coalition of Civil Society Groups Active in Lebanon, 2010.

18 For more on precariousness and vulnerability: Demetriou, 2015; Migrant Forum in Asia, 2012; Anderson, 2010.

19 Kanso, 2018.

20 Rose, 2016; Gemma, 2016; Mala, 2016.

21 Pande, 2012; Jureidini, 2009; Mala, 2016.
} 
arrival in Lebanon in 1999, she quickly realized that her otherness erased her humanity.22 After landing in Beirut, airport officers confiscated Rose's passport, locked her in a room with other newly-arrived migrant women, and refused to let her use the bathroom unless she first peed in her underwear. From her first moments in Lebanon, the state forced Rose into a state of dependency, increasing the power of the authorities and the employers, and decreasing her ability to self-advocate. National NGOs, international organizations, and the media primarily understand migrant domestic workers through a lens of victimhood, as Amrita Pande's research shows, echoing the rhetoric of dependency and weakness. ${ }^{23}$

There is an alternate narrative that combats the infantilizing rhetoric and violence found both within the kafala system, and the charity-based approach of many civil society and media groups: migrant domestic workers in Lebanon are not a singular group of low-skilled, uneducated "girls" from Asia and Africa, nor are they a monolith of victims. They reflect vast differences of nationality, politics, allegiances, education access, language, and goals for organizing. They can be powerful and adept at surviving an almostunsurvivable reality.

Migrant domestic worker activism often remains invisible to those outside their communities, partially because public action is fundamentally unsafe, or simply impossible. Pande's research demonstrates how workers transform the spaces that they do have access to - balconies, ethnic churches, and freelancers' apartments - into bases not just for community but also "powerful instances of resistances at the mesolevel."24 Migrant domestic worker Rose Mahi speaks to a similar phenomenon, in describing her relationship with other women migrant domestic workers in her building, via their balconies: "Despite not being able to communicate verbally, we managed to develop these techniques of mutual care." 25 We often identify resistance in public, collective action or private acts of rebellion, but Mahi and Pande show it is also nurtured in small collectives that share strategies, resources, and solidarity.

In recent years, Lebanese feminist communities and organizations have supported the community organizing of migrant domestic workers, offering space, resources, technical and logistics support, and meaningful solidarity. This has made certain forms of resistance visible. It also demonstrates the diversity of Lebanese feminisms, some of which had their origins in elite-led liberal reforms, ${ }^{26}$ and now include groups that represent anti-oppressive, class-conscious, queer, and radical organizing and ways of being. ${ }^{27}$ Although there is not a comprehensive, conclusive shift from charity to solidarity, and although NGOization can limit the effectiveness of grassroots movement building, feminist solidarity with migrant domestic worker activism is being theorized and practiced.

\footnotetext{
22 Rose, 2016.

23 Pande, 2012.

24 Pande, 2012, 14.

25 Mahi, 2017.

26 Stephan, 2014.

27 Kaedbey, 2014; H., 2015; Naber and Zaatari, 2014.
} 


\section{Embodying Complicity and Coloniality}

Complicity and coloniality are not only large, abstract forces. They are deeply personal questions and experiences, regardless of where you fall on the spectrums and intersections of privilege. Page encourages us to pay attention to the moments in which we are "pricked," when we feel a wound that represents someone else's experience of injustice. ${ }^{28}$ Our emotional investment may open channels of understanding to experiences that we do not share, but also has the potential to silence alternate explanations and give us a sense of ownership over that which we have no claim. ${ }^{29}$ As a US-American living, studying, and working in Beirut, I seek to understand the ways in which my own body contributes to persistent colonialism and structures of oppression, moments when I am complicit despite my best intentions, times when my own pricking means I overlook the wounds of others. I must map my own "embodied complicity," and the ways in which the feminist collectives that I am a part of and support both resist and fuel patriarchal and racist systems of control, the same systems that we seek to destroy.

People in Lebanon typically identify my body as Lebanese, Arab, or of Arab origin. When my body is perceived as Western, people call me an expat, never a migrant. My body, technically, could also be subject to kafala, but in reality it never is. I can travel freely in and outside the country, study, and speak out. I can benefit from intellectual analysis of migrant domestic labor. As a staff member of a center engaged in migrant worker rights, as an activist, and as a young academic, I profit from the kafala system. Even when Lebanese and Westerners condemn the practice, we benefit from the low-waged labor of people cleaning and caring for our offices, homes, universities, and hospitals.

Scholarship rarely examines complicity and coloniality as a part of daily life. However, these conversations of solidarity and identity are manifested in feminist activist spaces in Beirut, 30 and warrant full inclusion in the priorities and politics of broader women's rights movements, NGOs, international organizations, and academics. Investigating complicity and coloniality opens up difficult questions for activists in our choices of tactics, strategies, and daily decisions, and has material consequences.

\section{Complicit Feminisms versus Feminist Complicity}

Chandra Mohanty defines complicity as actions and words that serve the greater power structure, even when they are meant to be oppositional. ${ }^{31}$ Feminist complicity occurs when feminist discourse appropriates the language of the oppressor, and when feminist action actively supports the oppressors' structures. I argue that "complicit feminisms" explicitly align with local or global power structures that actively support oppression and violence. These include $20^{\text {th }}$ century colonial feminists, and $21^{\text {st }}$ century imperial feminists,

\footnotetext{
28 Page, 2017, 22.

29 Page, 2017, 25.

30 Radio Sawt, 2017.

${ }^{31}$ Mohanty, 2006, 9.
} 
such as those who lauded the US invasions of Iraq and Afghanistan as a liberatory force for women. ${ }^{32}$ This rhetoric went both ways; the US and UK governments adopted language of women's rights, and women's rights groups echoed governmental rhetoric about the need to "save" Iraqi and Afghan women. The USbased Feminist Majority Foundation, for example, called to "expand peacekeeping forces" to protect Afghan women's rights in 2009.33 They fulfilled Gayatri Spivak's omnipresent trope: white women arguing for white men to go save brown women. ${ }^{34}$

More needs to be written about complicit feminisms and the damage they have done. However, I choose to interrogate complicity within feminisms that actively work against multiple forms of oppression. These are not, broadly speaking, complicit feminisms. The feminist groups that support migrant domestic worker activists take a very different approach to feminist values and practice. They fit into what Nancy Naples and Manisha Desai discuss as counterhegemonic, decolonial, and anticapitalist feminisms, working for concrete alternatives to economic, political, and social inequity. ${ }^{35}$ Their tools include intentional changes to daily life and practice, expressions and actions of solidarity, and traditional activism such as protest, advocacy, and campaigning. Interrogating these spaces and philosophies can feel unnecessarily cruel at times, a symptom of the constant critique that social justice and feminist work has come to embody. However, it is essential to understand how complicity invades our daily lives and how feminist activists can be complicit, even when engaged in oppositional action.

In her investigation of solidarity between Palestinian and indigenous activists in Canada, Dana Olwan highlights the painful reality that genuine attempts at solidarity, regardless of good intentions, can be rife with complicity in oppression. ${ }^{36}$ The risks of complicity are not a reason to back away from the work entirely, but to reconsider our choice of tactics, our decision-making structures, and the visibility of bodies and identities in our movements. In the case of those with privilege, we need to examine where our liberation reinforces the domination of others. In the case of the struggle of migrant domestic workers in Lebanon, analyzing complicity means acknowledging the incredible strength of solidarity between migrant domestic worker activists and Lebanese feminist communities, learning from it, and finding both the moments in which the labor of solidarity reinforces systems of control - and moments where it is truly liberatory. It also means examining where migrant domestic workers become tokens and currency to prove the strength of good intentions, intersectionality, and inclusivity.

\section{Coloniality and Migrant Domestic Labor in Lebanon}

To discuss complicity, privilege, and the situation of migrant domestic workers in Lebanon also requires an understanding of coloniality, and its partnership with globalized capitalism. Anibal Quijano defines

\footnotetext{
32 Al-Ali and Pratt, 2009.

33 Kolhatkar and Rawi, 2009; Mohanty, 2006, 16.

34 Spivak, 1988.

35 Naples and Desai, 2009.

36 Olwan, 2015.
} 
coloniality as the ongoing legacy of colonialism, in the form of social, racial, and political hierarchies that are firmly integrated into modern society. ${ }^{37}$ As Sara Ahmed and María Lugones argue, colonialism is not an event that passed when new nation-states gained their independence from colonial powers, but an ongoing process that continues today. ${ }^{38}$ Lugones traces the origins of our contemporary conceptions of race and gender back to the colonial project, which formed a hierarchy that placed white men at the top, followed by white women, then men of color, and finally women of color. ${ }^{39}$ Lugones' framework grew out of the Americas, but it provides a key lens to understand migrant domestic labor in Lebanon. The divisions of labor in Lebanese society are highly gendered and racialized, by skin color and national identity, in ways that reflect this ongoing coloniality. The kafala system imports primarily Asian and African bodies, to perform low-waged labor in Lebanon and across the Middle East.

Focusing on coloniality in an analysis of feminism in Beirut risks re-centering the West, because it continues to position the West as the reference point. However, the history and present of coloniality help explain the global developments that produce the precarity and violence experienced by migrant domestic workers. Migrant domestic labor exists in Lebanon in part because of labor flows caused by globalized capitalism, and post-colonial understandings of race and gender. 40 No examination of power in Lebanon, including state-citizen and state-immigrant relationships, can be complete without acknowledging the forces that drew our current nation-state borders, our marking of gendered and racialized bodies, and the ongoing legacies of colonization.

As I type this on my balcony, at 7 am on a Monday, a migrant domestic worker - who I assume to be Ethiopian - cleans another balcony across the street. She does not respond to, or does not see, my wave. My body doesn't represent shared experience or struggle, but the forces that divide us, that handed her a bucket and rag on a weekday morning, but gave me coffee and a laptop.

\section{Encounter: Part 2}

The 2017 Workers' Day march combines public, private, and meso-level resistance. It is one of the few occasions where some workers are able to publicly organize and visibly oppose the unjust systems that deny them their rights, as others watch or cheer from their employers' balconies. Workers pursue this advocacy and activism despite immense opposition, from employers who question movements outside the home, to harassment on public transportation, to the Lebanese General Security, which has deported migrant women who are known to be activists. In two particularly high profile cases, Nepalese migrant domestic worker activists Sujana Rana and Roja Limbu were deported in 2016 without a trial or access to a lawyer, after their involvement with the Domestic Workers' Union, which was founded in 2015.41

\footnotetext{
37 Quijano, 2000, 167; Quijano, 2010.

38 Lugones, 2010; Ahmed, 2000.

39 Lugones, 2010; Mignolo, 2009.

40 Lugones, 2007.

41 Khawaja, 2016.
} 
The 2017 Beirut march was co-organized by the Alliance of Migrant Domestic Workers in Lebanon, a group of workers from different nationalities who advocate for their rights as a collective, while acknowledging their vast diversities of background, nationality, language, and experience. ${ }^{42}$ As Mahi writes about the Alliance, "We are a group of women who share one voice, because we all undergo similar problems and have had enough with the way things are." 43 The Alliance is one of many formal and informal groups and organizations led by migrant domestic workers, investing both in their communities based on nationality and in a broader, united struggle.

To organize the march, the Alliance partnered with other migrant domestic worker community activists groups and NGOs that work on issues facing migrant domestic workers, including the Anti-Racism Movement, which was founded by feminist activists, Kafa, and Amel Association International. Additional support, in the forms of logistics, volunteers, and promotion, came from feminist and leftist collectives such as the Feminist Bloc, Sawt al-Niswa, and the Socialist Forum. ${ }^{44}$ One of the roles of the feminist collectives and NGOs was to handle the background tasks and communication with the Lebanese authorities that make a public march possible, in an expression of solidarity. This is both a tactical choice, and a reality of working within the restrictions facing migrant domestic worker activism. In order to obtain government permission for a protest, three Lebanese citizens must provide their identification and signatures at the relevant municipality or governorate office. A foreigner, even with "legal" status, cannot be included. These state regulations prevent migrant workers from officially taking responsibility of their own march. Migrant domestic worker activists and allies faced similar restrictions in 2015, when they formed the Domestic Workers' Union in Lebanon. As migrants cannot unionize, the union's president is Lebanese, and the Lebanese state has refused to formally recognize the union. ${ }^{45}$ Legally and physically, Lebanese bodies mitigate the risks for migrant domestic workers, in an environment that is anything but secure for an African or Asian body. As a volunteer, I envisioned that our Lebanese and Western bodies could create space away from harassment and control, an alternative mode of being.

On April 30, 2017, the volunteer teams - mostly made up of young Lebanese activists and students arrived hours before the march began. The Lebanese leaders of the security team gave each of us a colored armband, to make ourselves easy to identify for the protestors, and clear instructions: Watch the people watching the march. Cut off harassment - physical or verbal - by putting your own body in between protestors and observers. Watch the men in the march. Make sure they don't take up too much space or attention. Watch the police. If there is a security issue, intervene. Do not let a migrant worker get arrested at any cost. Put yourself in handcuffs instead. You have Lebanese and Western passports and privilege, so an arrest doesn't mean deportation.

\footnotetext{
42 Mahi, 2017.

43 Mahi, 2017, 169.

44 The Alliance of Migrant Domestic Workers, 2017.

$45 \mathrm{Su}, 2017$.
} 
For people who have participated in organized public protest or march before, these directions are familiar. However, both migrant domestic worker activists and Lebanese volunteers gave us a final instruction: Make sure the Ethiopians don't take over the march. Don't let them overshadow the unified message with their national pride. Don't let their flags get in front of the main Alliance of Migrant Domestic Workers' banner.

At the time, I didn't question the instruction. As an outsider to these communities and to Lebanon, I had resolved to follow the lead of others as much as possible. I wasn't yet working directly with the many communities of migrant domestic workers and migrant workers. I knew that migrant domestic workers were not a monolithic, homogenous group, but I didn't yet understand the political and social divisions between and within national groups. I didn't know that there were more than 100,000 Ethiopian migrant domestic workers in Lebanon, ${ }^{46}$ and that they are one of the most highly stigmatized groups by agencies, employers, and the state.

Just like with any diverse constituency, it is challenging to build concrete alliances among migrant domestic workers from varied political, linguistic, religious, and national backgrounds. And just like other protest marches - such as those held to commemorate International Women's Day - some groups want their banner to be the most visible. The organizers, however, wanted a unified message: rights for all, not for some, and solidarity in shared struggle. As a volunteer, I idealized this narrative, of power, unity, and opposition, and saw the march as its symbol.

The ad-hoc security team of mostly Lebanese volunteers divided into places along the route. A team leader assigned me to the beginning of the march, and we started walking, following the volunteers who had set the route. Alliance representatives of different nationalities marched in the middle of the street, with a banner that read, "Abolish the Sponsorship System \& Include Domestic Workers in the Labor Law - لإلغاء as the agreed-upon message of the march.47 However, the streets were wide and protesters were excited, wanting to move faster and faster. As I was warned, a group of Ethiopian women on my side of the march pushed forward, raising their flags high. Other marchers started calling on me, directly, to prevent the Ethiopians from overtaking the main banner.

I tried to comply. I didn't want to police, to yell, to control, so I resorted to other tactics. I asked people to step back, to pause. I bargained. Nothing worked, so I ended up at what seemed like self-ridicule. I found myself walking backwards, dancing with many of the marchers, and pleading "shway shway, slow down, slow down," in between the chants to abolish the kafala system. And when I danced, the other marchers laughed, and slowed their own groups down.

The march was deemed a success: no security incidents and some news coverage. However, I left unsettled, uncomfortable, and complicit in this unnamed project of control. I felt like a chaperone on a school field trip. Some migrant domestic worker activists had been instrumental in planning the march, but

46 Khawaja, 2016.

${ }^{47}$ Chamoun and Ayoub, 2017. 
march organizers and volunteers bused other workers in, gave them water, guided them through an experience, and sent them home. I had shown up as a volunteer, ostensibly to decenter my voice and my authority. However, my armband and my appearance were associated with a relative amount of power. Protestors looked to me for intervention when emotions became heated - both with men on the street and in tensions between marchers. We all knew that my privilege could shape the emotional, legal, and physical trajectory of bodies in the march. I used that power to control how people expressed themselves. And unsurprisingly - marchers and other volunteers used my body and my voice to achieve their own goals.

Sometimes marches are designed as expressions of anger, but in reality serve as a proxy for real change. In my experience, this does not ring true for the 2017 Workers' Day March. To speculate, the Lebanese state authorities may permit the march because it represents a contained moment of managed rage and not a real threat to the system, but to participants it is anything but this. As Gemma shared with Kohl, her experience of rescuing workers of different nationalities during the 2006 Israeli war on Lebanon taught her about the importance and long-term labor of transnational work, and this solidarity gave her hope that the situation could actually change. 48

\section{Reflecting on the Workers' Day March}

Ahmed's Strange Encounters offers a meditative approach to the complexities of coloniality and the role of strangers and strange-ness in a globalized society. She calls for us to investigate the legacies of colonialism on the ground: "If we are to think of post-coloniality as that which is yet to come...then we need to pay attention to how and where colonialism persists after so-called decolonisiation." 49 As Olwan's work shows, coloniality often persists within the bodies and minds of those who oppose it. These are not academic inquiries; they are rooted in the practices of feminist activism, and daily encounter with our communities, ourselves, and others. In the march, I found an unexpected confrontation with the reality of my embodied complicities - physically, linguistically, and symbolically.

Why is it important to work through moments of complicity? In looking at the literature on Lebanese feminisms and Arab women's movements more broadly, scholarship has addressed questions of complicity and coloniality primarily through a critique of NGOization and the influence of foreign funding and priorities on women's movements. But in feminist spaces in Beirut, I hear repeated questions about how best to enact solidarity and the most effective and ethical forms of organizing, not only debates about the risks of NGOization and dilemmas of accepting funding. These questions are personal and political, and they have real consequences. Should you support an imperfect law, because it is an important institutional step to criminalize family violence, or oppose the law because it enshrines "marital rights" to intercourse into the Lebanese penal code? ${ }^{50}$ Should you speak up at your family's dinner table, or stay silent to protect

\footnotetext{
48 Gemma, 2016.

49 Ahmed, 2000, 13.

50 KAFA, 2014, 6.
} 
yourself? Should you report harassment or assault, or will that give the institution or the government further power to police and criminalize marginalized bodies? Should you talk to your landlord about the time you heard her screaming at the "maid?" Should you join the Alliance of Migrant Domestic Workers or the Domestic Workers' Union, and put your own legal status in Lebanon - and your family's security - in jeopardy?

Even on the day of their march, Lebanese and others who meant to help were, on some level, not letting migrant domestic workers make their own choices. By sacrificing workers' individual autonomy for the needs of the group, even with good intentions, we echoed the infantilizing language of the kafala system's dominant narrative. Workers were told what to do and how to act by volunteers, as a way to protect them from external threats and each other. This power dynamic replicates the patriarchal state's control of the low-waged, female, Asian and African body. Yes, we made space for protest against the kafala system, the Lebanese authorities, and global capitalist economy. However, on April 30, 2017, that space was created according to the volunteers' ability to make the rules, not the workers. The planning process for the march may have been more inclusive, in the safety of private spaces. In public, however, with hundreds of marchers and volunteers joining for the first time, the organizers' labor of long-term solidarity work did not change the interpersonal, racialized hierarchies of daily life in Lebanon.

It must be acknowledged that workers themselves have agency in how they respond to, and use, these power dynamics. Policing by volunteers was not solely a top-down behavior. Migrant domestic worker activists participating in the march and among the organizing team understood these hierarchies and the politics of bodily privilege. Workers thus explicitly called upon volunteers to play the roles of police and guardian. Like the kafala system, control at the march was justified by rhetoric of protection, both from violent external forces and from internal divisions within and between migrant worker communities.

Lebanese society imposes hierarchies among workers, on lines of nationality, skin color, and race, also reflecting the relative strength of the respective national governments, embassies, and consulates in demanding fair labor standards. As Marie-José L. Tayah notes, bilateral agreements between the Lebanese government and countries of origin supersede the standard unified contract, "promoting a race to the bottom in the working and living conditions of domestic workers from different nationalities and encouraging stereotypes about the quality of the work performed by women from certain countries." 51 Hierarchies also reflect the history of feminized domestic labor in Lebanon, which shifted from employment of Arab women on the margins, to foreign Asian and African women in the 1980s and 1990s, 52 who were perceived to be more "submissive." ${ }^{3}$ Nayla Moukarbel's interviews with Lebanese employers illustrate perceptions of different temperaments between nationalities, with Sri Lankans seen as more submissive and thus desirable, compared to "stubborn" and "arrogant" Ethiopians, and Filipinas considered as more

\footnotetext{
51 Tayah, 2017, 146-47.

52 Jureidini, 2009; Pande, 2012.

53 Pande, 2012, 5.
} 
educated about their rights and less naïve. ${ }^{54}$ These stereotypes correlate to institutionalized wage disparities between women of different nationalities. Filipina workers are typically paid the most, although data shows that $34.6 \%$ still have a salary of less than $\$ 300$ a month. 55 In Lebanon and globally, the power differential between employer and domestic worker is further exacerbated when the latter inhabits a minority, migrant, immigrant, and/or black body. 56

In slowing down the Ethiopian groups at the request of women from other nationalities, I wonder if I not only reinforced narratives of control of migrant domestic workers as a whole, but also the national stereotypes that Moukarbel identifies. It is significant that volunteers were not instructed to watch for any group overtaking the march, but specifically Ethiopian migrant domestic workers, who have bodies that are marked as both less educated and harder to control. As activists aligned with the cause of migrant domestic workers, it is all too easy to romanticize their struggle and ignore these dynamics - even when we share the goals of improved labor rights, justice, and gender and racial equity. And when we engage in selfcritique, we can become paralyzed by questions of embodied complicity and privilege, losing sight of the work in circular debates of positionality, representation, and credibility.

This encounter also prompts a reflection on the meaning of the kafala system itself, and the way it is mirrored within the relationship of feminist groups, NGOs, and migrant domestic workers' efforts to organize.57 Just as employers sponsor a worker, feminist groups and NGOs have taken on a role of sponsorship for burgeoning and established migrant domestic worker collectives. The ILO, for example, collaborated on the process to create Lebanon's Domestic Workers' Union, involving migrant domestic worker activists, the NGOs Anti-Racism Movement, Insan Association, Frontiers Ruwad, and KAFA, the National Federation of Employees' and Workers' Unions in Lebanon, and the International Domestic Workers Federation. ${ }^{58}$ At a much smaller, daily scale, feminist groups use their access, relative privileges, and resources to provide physical meeting space, logistics support, and advocacy work to migrant domestic workers, who physically and legally cannot have a space of their own or organize for their rights. This can be a rare form of true solidarity, an investment of time, energy, and resources to support migrant domestic workers' amplification of their struggle.

Of course, just as migrant domestic workers are not a monolith, neither are Beirut's feminist communities and organizations, and other NGOs. They all have their own politics, approaches, and rhetoric around migrant domestic workers.

This sponsorship can also fit into the neoliberal frameworks that guide the priorities of many international donors and NGOs. The past ten years have seen increased campaigning, legal advocacy, and provision of

\footnotetext{
54 Moukarbel, 2009, 148.

55 International Labour Organization, 2016, 28.

56 Romero, 1992, 132; Jureidini, 2009.

57 I am grateful to Dr. Sara Mourad at the American University of Beirut for helping make this connection more explicit, and pushing me to interrogate the multiple meanings of kafala.

58 Tayah, 2017, 148.
} 
psychological, medial, and legal services, by national and international NGOs in the Middle East, for migrant domestic workers. However, Tayah argues that these initiatives are rarely grounded in the demands of migrant domestic workers, but instead result in "a plethora of well-intentioned but incongruent programmes and services." 59

It is no accident that this mirrors a broader critique of NGOs, and the NGOization of the Arab women's movement. The decade after the 1995 Fourth International World Conference on Women in Beijing saw a proliferation of women's rights NGOs in the Arab region, which many argue transformed a vibrant, grassroots women's movement into siloed, professionalized organizations bound by donor priorities. ${ }^{60}$ This narrative risks romanticizing the past, 61 but does acknowledge the reality that NGOs face challenges in addressing intersectional problems, as they rely on project-based funding from largely international donors, subsequently prioritize a "middle-class" form of work and communication, and thus seldom hire those most affected by the issues. ${ }^{62}$ Longer-term movement building and cross-sectorial alliances are subsumed by grant reports and competition between groups for the same limited resources. And when migrant domestic workers become "beneficiaries," instead of allies and partners, organizations and the individuals who comprise them more easily overlook the diversity of migrant domestic workers and their myriad experiences and goals. Even if unintentional, homogenization is a slippery slope to erasure of cultural and historical difference, a key strategy of neoliberalism.

Many of the feminist communities supporting the Workers Day march actively oppose this paradigm. And, as Tayah argues, some NGO initiatives collaborating with migrant domestic workers are becoming more responsive to workers' demands, needs, and partnership. This may primarily be because migrant domestic worker activists in the Middle East have been able to increase their collective organizing around nationality and sectorial work, but perhaps also - in the case of Beirut - because feminist communities are getting better at listening.

With this analysis, the feminist groups, volunteers, and NGOs' acts of support for migrant domestic worker communities do redistribute a tiny amount of power into the hands of the workers, even as they replicate the dynamics of sponsorship. Mentorship and relationships are key tenets of feminist movements, and yet can still reflect an individual's internalized understanding of the "racialized and colonized poor" as simultaneously vulnerable and "morally bankrupt...excluded from a privileged liberal subjecthood."63 Even when racism is outwardly condemned, class difference and superiority are not erased. And yet, when migrant domestic workers do live in precarious situations, sponsorship and sharing of resources are the minimum steps of solidarity and movement building. What alternative is there?

\footnotetext{
59 Tayah, 2017, 147.

60 Jad, 2016; Stephan, 2012; Mitri, 2015.

61 Kaedbey, 2014.

$62 \mathrm{Jad}, 2016,44$.

63 Hong, 2015, 13.
} 


\section{In Conclusion: What Do We Do with Our Complicity?}

Constant questioning is one of the only weapons we have against complicity. In the march, I found myself saying, "slow down, slow down, this is not the right time." These words have been said by those with power, to people fighting for their rights, for centuries. Were those words justified, because the systems that we are fighting against are so much worse? Does the violence of the kafala system, the current dynamic of deportation, and the physical, emotional, and legal dangers faced by workers vindicate that use of power? In the case of the march, when there was a clear need for volunteer support, should we - as volunteers have refused to do certain jobs because our authority might theoretically reinforce hierarches of privilege? Should we have refused to intervene in disputes between different communities of migrant domestic workers, rather than mediating conflict that could have been productive? When people's safety is threatened, when you know what could happen in the event of an arrest, how do you make space for these conversations?

Some of these debates, of course, have and continue to occur between migrant domestic worker activists and their Lebanese allies, but not at a public scale. At the time of the 2017 march, this work was not visible to me. I intentionally chose to examine this encounter with my own good intentions, at a moment of complicity when I did not have deep insider knowledge, to understand the damage that even feminist goodwill can cause. ${ }^{64}$

Complicity is, in a certain sense, unavoidable. I reflect upon the march precisely because of the incredible solidarity between migrant domestic workers and young feminist communities in Beirut. Their expressions of feminist solidarity move far beyond lip service, in an example of a complex feminism that counters intersecting forms of oppression. It is a feminism that knows that movements for liberation are contextual and interconnected, that the liberation of Lebanese women cannot be achieved if society's most marginalized are excluded. In a historic context where women's movements are dominated by elite women and their associations, ${ }^{65}$ this type of feminism is not the norm. This feminism is resistant both to the patriarchal and oppressive elements of society, and the colonial, imperial, and classist elements of more mainstream Lebanese and global feminisms. I thus offer this reflection not as a uniform critique of feminist movements, but as a celebration and a commitment to difficult questions. Even within the best spaces and movements, complicity is a day-to-day inevitability when our bodies themselves are markers of privilege.

Sara Ahmed argues that we must understand how power is constructed in order to dismantle it, and to envision an alternate version of the world. Workers Day is an attempt to enact this alternate vision. It is no surprise that our interpersonal dynamics will reflect the social hierarchies of the world in which we all grew up. The question is thus not if we are complicit, but what we do with our awareness of that complicity. It is not enough to investigate how power is constructed in the forces that govern our lives - like the kafala

\footnotetext{
64 Incite! Women of Color Against Violence, 2017; Flaherty, 2016.

65 "Women's Movements in Lebanon," 2017.
} 
system and the post-colonial nation-state. We must also interrogate how power exists and changes within and between our own bodies. 
Kohl 4.1

\section{References}

Ahmed, Sara. Strange Encounters: Embodied Others in Post-Coloniality. London and New York: Routledge, 2000.

Al-Akhbar. "Lebanese Labor Ministry Rejects Creation of Domestic Workers Union." Al-Akhbar. January 27, 2015. https://search.proquest.com/docview/1648439631? accountid=8555.

Al-Ali, Nadje, and Nicola Pratt. What Kind of Liberation? Women and the Occupation of Iraq. University of California Press, 2009.

Anderson, Bridget. "Migration, Immigration Controls and the Fashioning of Precarious Workers." Work, Employment and Society 24, no. 2 (2010): 300-317. https://doi.org/10.1177/0950017010362141.

Chamoun, Hassan, and Joey Ayoub. "We Are Not Slaves, We Want Our Rights': Lebanon's Migrant Domestic Workers March on Labour Day." Global Voices. May 12, 2017. https://globalvoices.org/2017/05/03/we-are-not-slaves-we-want-our-rights-lebanons-migrant-domesticworkers-march-on-labour-day/print/.

Coalition of Civil Society Groups Active in Lebanon. "Joint Universal Periodic Review Submission on Economic and Social Rights." 2010. http://lib.ohchr.org/HRBodies/UPR/Documents/Session9/LB/ANND_CoalitionofCivilSocietyGroupsActi veinLebanon_JS.pdf.

Demetriou, Daphne. "Tied Visas' and Inadequate Labour Protections: A Formula for Abuse and Exploitation of Migrant Domestic Workers in the United Kingdom." Anti-Trafficking Review, no. 5 (2015): 69. https://doi.org/10.14197/atr.20121555.

Flaherty, Jordan. No More Heroes: Grassroots Challenges to the Savior Mentality. AK Press, 2016.

Gemma. "The Road to Dissent." Kohl: a Journal for Body and Gender Research 2, no. 2 (2016): 135-139. http://kohljournal.press/the-road-to-dissent/.

H., Sanaa. "A Political Movement in Lebanon? A Conversation on Feminism and Queerness." Kohl: a Journal for Body and Gender Research 1, no. 1 (2015): 92-104. http://kohljournal.press/a-politicalmovement-in-lebanon-2/

Hamati, Roula. "Trapped: Migrant Domestic Workers in Lebanon." Insan Association. Beirut, 2016. http://www.insanassociation.org/en/images/Trapped.Compressed.pdf

Hamill, Kathleen. "Reforming the 'Sponsorship System ' for Migrant Domestic Workers: Towards an Alternative Governance Scheme in Lebanon." KAFA. 2012. http://www.kafa.org.lb/studiespublicationpdf/prpdf47.pdf

Hong, Grace Kyungwon. "Introduction." In Death Beyond Disavowal: The Impossible Politics of Difference. University of Minnesota Press, 2015.

Incite! Women of Color Against Violence. The Revolution Will Not Be Funded: Beyond the Non-Profit Industrial Complex. Duke University Press, 2017.

International Labour Organization. "A Study of Employers of Migrant Domestic Workers in Lebanon." Geneva, $2016.2 \quad$ http://www.llo.org/wcmsp5/groups/public/---arabstates/---robeirut/documents/publication/wcms_524149.pdf.

—. "Employer-Migrant Worker Relationships in the Middle East: Exploring Scope for Internal Labour Market Mobility and Fair Migration." Beirut, 2017. http://www.llo.org/wcmsp5/groups/public/--- 
arabstates/---ro-beirut/documents/publication/wcms_552697.pdf

Jad, Islah. "The 'NGOization' of the Arab Women's Movements." Al-Raida, no. 100 (2003): 38-46. http://iwsawassets.lau.edu.lb/alraida/alraida-100.pdf.

Jureidini, Ray. "In the Shadows of Family Life: Toward a History of Domestic Service in Lebanon." Journal of Middle East Women's Studies 5, no. 3 (2009): 74-101. http://muse.jhu.edu/journals/journal_of_middle_east_womens_studies/v005/5.3.jureidini.html\%5Cnhtt p://muse.jhu.edu/journals/journal_of_middle_east_womens_studies/summary/v005/5.3.jureidini.html.

Kaedbey, Deema. Building Theory Across Struggles: Queer Feminist Thought from Lebanon. Ohio State University, 2014.

KAFA. "KAFA (Enough) Violence \& Exploitation Annual Report, 2014 Highlights." Beirut, 2014. http://www.kafa.org.lb/StudiesPublicationPDF/PRpdf-82-635689245975040950.pdf.

Kanso, Heba. "Trapped by the System, Ethiopian Workers in Lebanon See No Freedom." Reuters. 2018. https://www.reuters.com/article/us-lebanon-migrants-irregular/trapped-by-the-system-ethiopianworkers-in-lebanon-see-no-freedom-idUSKCN1FZ195

Khawaja, Bassam. "Lebanon Deports Domestic Worker Rights Organizer." Human Rights Watch. December 13, 2016. https://www.hrw.org/news/2016/12/13/lebanon-deports-domestic-worker-rightsorganizer.

Kolhatkar, Sonali, and Mariam Rawi. "Why Is a Leading Feminist Organization Lending Its Name to Support Escalation in Afghanistan?" AlterNet. 2009. https://www.alternet.org/story/141165/why_is_a_leading_feminist_organization_lending_its_name_to _support_escalation_in_afghanistan.

Lugones, María. "Heterosexualism and the Colonial / Modern Gender System." Hypatia 22, no. 1 (2007): 186-209.

—_. "Toward a Decolonial Feminism." Hypatia 25, no. 4 (2010): 742-59. https://doi.org/10.1111/j.15272001.2010.01137.x.

Mahi, Rose. "The Difference Self-Organising Makes: The Creative Resistance of Domestic Workers." Domestic Workers Speak: A Global Fight for Rights and Recognition. 2017. 165-169.

Mala. "Migrating to the Lebanese Civil War." Kohl: a Journal for Body and Gender Research 2, no. 2 (2016): 132-134. http://kohljournal.press/migrating-to-civil-war/.

Mignolo, Walter D. "Epistemic Disobedience, Independent Thought and De-Colonial Freedom." Theory, Culture \& Society 26, no. 7-8 (2009): 1-23. https://doi.org/10.1177/0263276409349275.

Migrant Forum in Asia. "Policy Brief No 2: Reform of the Kafala (Sponsorship) System." Migrant Forum in Asia. 2012. http://www.mfasia.org/resources/publications.

Ministry of Labour Lebanon. "Information Guide for Migrant Domestic Workers in Lebanon." International Labour Organization. Beirut, 2012.

Mitri, Dalya. "From Public Space to Office Space: The Professionalization/NGO-Ization of the Feminist Movement Associations in Lebanon and Its Impact on Mobilization and Achieving Social Change." Civil Society Knowledge Centre. 2015.2 http://civilsocietycentre.org/file/frompublicspacetoofficespaceenpdf-0/download?token=qydDzR59

Mohanty, Chandra Talpade. "US Empire and the Project of Women's Studies: Stories of Citizenship, Complicity and Dissent." Gender, Place, and Culture 13, no. 1 (2006): 7-20. 
https://doi.org/10.1080/09663690600571209.

Moukarbel, Nayla. Sri Lankan Housemaids in Lebanon. Amsterdam University Press, 2009. https://doi.org/10.5117/9789089640512.

Naber, Nadine, and Zeina Zaatari. "Reframing the War on Terror: Feminist and Lesbian, Gay, Bisexual, Transgender, and Queer (LGBTQ) Activism in the Context of the 2006 Israeli Invasion of Lebanon." Cultural Dynamics 26, no. 1 (2014): 91-111. https://doi.org/10.1177/0921374013510803.

Naples, Nancy A, and Manisha Desai. "Introduction." Women's Activism and Globalization: Linking Local Struggles and Transnational Politics. New York: Routledge, 2002. 1-43.

Olwan, Dana M. "On Assumptive Solidarities in Comparative Settler Colonialisms." Feral Feminisms, no. 4 (2015): 89-102. http://www.feralfeminisms.com/wp-content/uploads/2015/12/ff_On-AssumptiveSolidarities-in-Comparative-Settler-Colonialisms_issue4.pdf

Page, Tiffany. "Vulnerable Writing as a Feminist Methodological Practice." Feminist Review 115, no. 1 (2017): 13-29. https://doi.org/10.1057/s41305-017-0028-0.

Pande, Amrita. "From 'Balcony Talk' and 'Practical Prayers' to Illegal Collectives: Migrant Domestic Workers and Meso-Level Resistances in Lebanon." Gender \& Society 26, no. 3 (2012): 382-405. https://doi.org/10.1177/0891243212439247.

Quijano, Anibal. "Coloniality and Modernity/Rationality." Cultural Studies 21, no. 12 (2010): 168-78. https://doi.org/10.1080/09502380601164353.

—. "Coloniality of Power, Eurocentrism, and Latin America." Nepantia: Views from the South 1, no. 3 (2000): 533-80.

Radio Sawt. "Building Bridges of Solidarity." Sawt al Niswa, 2017. https://soundcloud.com/radiosawt/solidarity-as-a-bridge-we-

build?utm_source=soundcloud\&utm_campaign=share\&utm_medium=facebook.

Romero, Mary. Maid in the U.S.A. New York: Routledge, 1992.

Rose. "Beirut's Welcome." Kohl: a Journal for Body and Gender Research 2, no. 2 (2016): 125-131. http://kohljournal.press/beiruts-welcome/.

Spivak, Guyatri. "Can the Subaltern Speak?" Colonial Discourse and Postcolonial Theory: A Reader. New York: Columbia University Press, 1988. 66-111.

Stephan, Rita. "Four Waves of Lebanese Feminism." E-International Relations. 2014. http://www.eir.info/2014/11/07/four-waves-of-lebanese-feminism/\#.VF0-gvPV_k0.twitter.

_ . "Women's Rights Activism in Lebanon." Mapping Arab Women's Movements. American University in Cairo Press, 2012. 11-32. http://www.jstor.org/stable/j.ctt15m7hb5.10.

Su, Alice. "Slave Labour? Death Rates Double for Migrant Domestic Workers in Lebanon." IRIN. May 15, 2017. https://www.irinnews.org/feature/2017/05/15/slave-labour-death-rate-doubles-migrant-domesticworkers-lebanon.

Tayah, Marie-José L. "Claiming Rights Under the Kafala System." Domestic Workers Speak: A Global Fight for Rights and Recognition. 2017. 146-159.

The Alliance of Migrant Domestic Workers. "Join Us! Workers' Day 2017." Facebook Event. 2017. https://www.facebook.com/events/148992548967059/.

"Women's Movements in Lebanon." Civil Society Knowledge Centre, Lebanon Support. 2017. http://civilsociety-centre.org/gen/women-movements-timeline/4938. 
